Portland State University

PDXScholar

6-16-2021

\title{
North American Expatriates in Mexico: a Discourse Analysis of Facebook Groups
}

\author{
Liliana Carolina Brock \\ Portland State University
}

Follow this and additional works at: https://pdxscholar.library.pdx.edu/honorstheses

Part of the Critical and Cultural Studies Commons, International and Intercultural Communication Commons, Migration Studies Commons, and the Social Media Commons Let us know how access to this document benefits you.

\section{Recommended Citation}

Brock, Liliana Carolina, "North American Expatriates in Mexico: a Discourse Analysis of Facebook Groups" (2021). University Honors Theses. Paper 1074.

https://doi.org/10.15760/honors.1100

This Thesis is brought to you for free and open access. It has been accepted for inclusion in University Honors Theses by an authorized administrator of PDXScholar. Please contact us if we can make this document more accessible: pdxscholar@pdx.edu. 
North American Expatriates in Mexico: A Discourse Analysis of Facebook Groups

by

Liliana Carolina Brock

An undergraduate honors thesis submitted in partial fulfillment of the requirements for the degree of

Bachelor of Arts

in

University Honors

and

International and Global Studies: International Development

Thesis Adviser

Dr. Stephen Frenkel

Portland State University 


\begin{abstract}
North American expatriates in Mexico often live in enclaves or affluent communities at a fraction of what it would cost in the US or Canada. Despite living in Mexico for years, many expatriates are poorly integrated into Mexican culture and society. This integration is made more difficult because many are unable to speak Spanish fluently. Instead, expatriates rely on English language Facebook groups to help them navigate life in Mexico. While scholars have explored the intersections of communication and interculturalism in expatriate communities, comparatively few have explored how the internet and the presentation of self on social media (specifically Facebook) influence expatriates' relative integration or isolation. Using qualitative discourse analysis, this study focuses on five major Facebook groups for expatriates in Mexico to determine the different functions of these communities. An emphasis will be placed on how North Americans learn about and perceive safety. The analysis suggests that expatriates use Facebook groups to compensate for their lack of networks and cross-cultural skills to enhance their outcomes and minimize the risks in a foreign country.

Keywords: North Americans, expatriates, migration, Mexico, social capital, social networks, social media
\end{abstract}




\section{Contents}

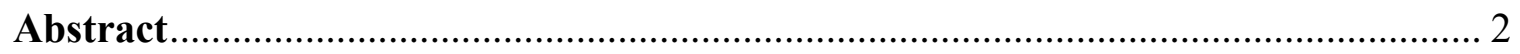

North American Expatriates in Mexico: A Discourse Analysis of Facebook Groups. 4

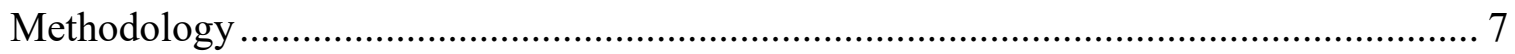

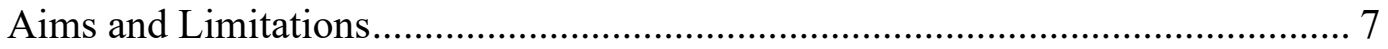

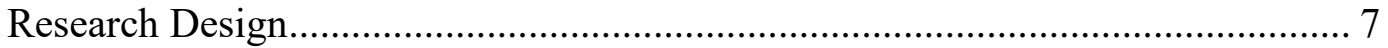

History of the North American Community in Mexico ............................................... 8

North Americans in Mexico: Locations and Numbers .............................................. 10

North American Migration Process and Social Media .............................................. 13

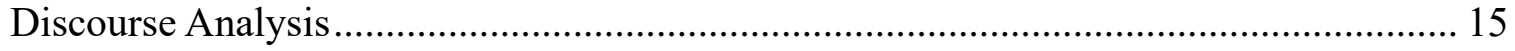

What is the Capacity of Facebook to Generate Social Capital Returns?........................ 15

The Role of Facebook in Expatriates' Decision Making ................................. 16

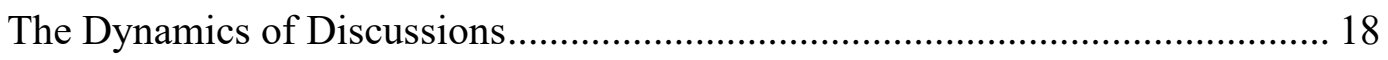

How does the Usage of Facebook Groups Influence Online-Offline Social Capital?..... 20

Safety Concerns Bring Expatriates Together ................................................. 20

Social Capital Reinforcements............................................................ 23

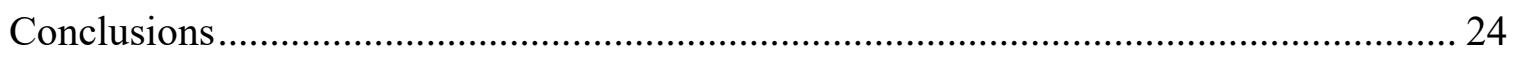

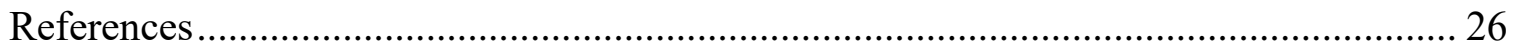




\section{North American Expatriates in Mexico: A Discourse Analysis of Facebook Groups}

Many North Americans envision themselves retiring to places with warmer weather, close to water, and generously sized housing with plenty of green spaces. However, the average person with a middle-class income has difficulty affording these in the United States or Canada when considering retirement. As an alternative, some North Americans move to Mexico to continue living a middle-class lifestyle during their retirement years. Mexico's low cost of living combined with its rich and diverse geographical features translates into their chance to live affordably in warmer weather places close to nature (see Figure 1). In addition, some expatriates can even afford amenities like maids and gardeners for only a fraction of what it would cost in their home countries (Goss, 2019).

\section{Figure 1}

Map of geographical features of Mexico

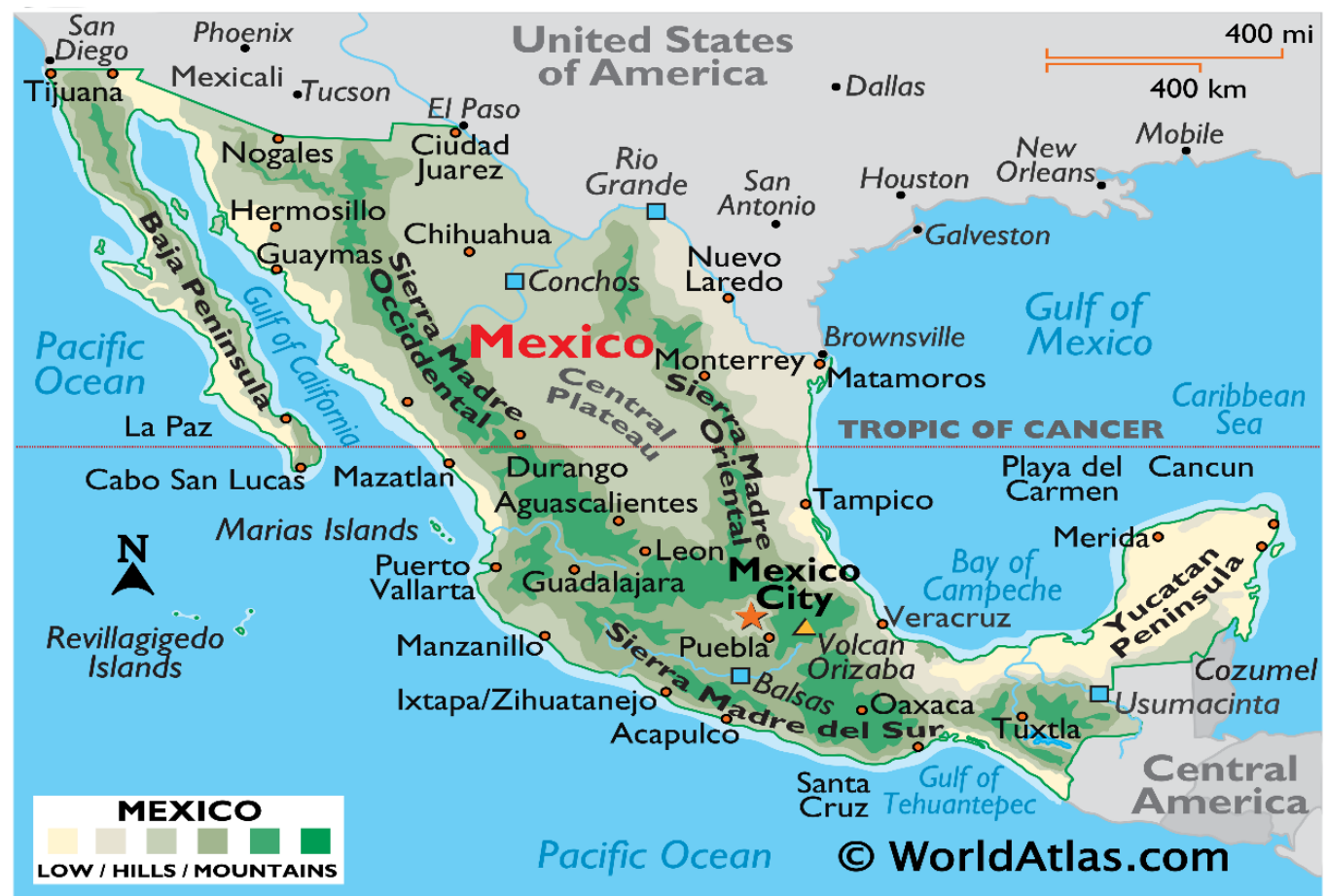

Note. The map shows the different geographical features of Mexico and their locations. From Mexico Maps \& Facts. (n.d.). WorldAtlas. https://www.worldatlas.com/maps/mexico 
Moving to a foreign country such as Mexico comes at the cost of learning a new way of life. This is especially true for expatriates who do not speak Spanish. This cost was verbalized in a Facebook post discussing the difficulties of transitioning from the United States to Mexico, an expatriate said, "as with anything in life, [...]. You get out what you put in. [...] We love it [Mexico], and it loved us back." The added difficulty expatriates experience when they cannot speak Spanish fluently (sometimes after living in Mexico for years), not only keeps them from partaking in the local community at large (Banks, 2004), but also makes them reliant on English services and information that generally come from other expatriates (Truly, 2002). Facebook groups for expatriates facilitate access to the information seasoned expatriates have from living or visiting Mexico for years.

It is normal to see Facebook posts asking seasoned expatriates, "where do they live?" "why did they move there?" "what do they do where they live?" "what do they like about where they live?" "how much does it cost where they live?" and "where is it affordable?" While most of these questions come with claims of interest in learning about the lifestyle and culture in different parts of Mexico, most inquiries seem to be about saving money. Traveling through different parts of Mexico to have these life experiences requires a significant investment in time and money. In addition, many questions relate to perceptions of safety. Interestingly, for reasons of cultural homogeneity, safety and economics, a considerable number of expatriates live in enclaves. These reasons also seem to explain why Facebook groups for expatriates are popular: expatriates lack the cross-cultural knowledge and cross-cultural skills to counter their lack of social capital in a foreign country. 
Facebook groups for American expatriates in Mexico have been active since at least 2008 and range in scale from 200 to 52,000 members (and counting). ${ }^{1}$ The internet expansion in Mexico $^{2}$ and the fast-paced advancement and use of digital technology provide a window into understanding expatriate communities. While scholars have explored the intersections of communication and interculturalism in expatriate communities (Alcocer-Berriozabal, 2000; Banks, 2004, 2009; Croucher, 2009; Goss, 2019; Kunz, 2020; Truly, 2002), there is little research on how expatriates use and apply the resources embedded in virtual communities to cope with their lives in a foreign country.

In this paper, I argue that North American expatriates in Mexico resort to social media, specifically Facebook groups, to learn about Mexico and Mexican culture. My argument is based on the observation that these groups have the purpose to and the purpose of compensating for expatriates' lack of networks and cross-cultural skills. These groups provide a virtual space where expatriates seek and provide information in English about living in Mexico. In addition, expatriates use Facebook groups to create a network focused on gaining cross-cultural knowledge and gaining and maintaining their social capital in a new location.

${ }^{1}$ Virtual communities like Listservs and Myspace did for expatriates in the 1980s, 1990s and early 2000s what Facebook groups have done in the last 13 years.

${ }^{2}$ The internet penetration in Mexico was a little over 5 percent in 2000, and by 2020 it increased to 66 percent. See Mexico Internet Users. (n.d.). Retrieved May 2, 2021, from https://www.internetlivestats.com/internet-users/mexico/ and Newman, N., Fletcher, R., Schulz, A., Andi, S., \& Kleis Nielsen, R. (2020). Reuters Institute Digital News Report 2020. 112. 


\section{Methodology}

\section{Aims and Limitations}

The aims of this paper are not to expose individual expatriates or to distinguish between them through comparisons and categorizations. The aim of this paper is to investigate how expatriates, as a group, use Facebook groups to navigate their life in Mexico. This paper does not differentiate North Americans by ethnicity, race, or heritage (e.g., Mexican American, African American, Hispanic, white, French Canadian, etc.). It makes the generalization that people who join these English-speaking groups identify as Canadian or American to maintain a simple yet reliable focus. In addition to these generalizations, this research also considers that people could be identified easily even if personal details are concealed (Markham, 2012; Willis, 2018). To alleviate this concern, the representational quotes used in this manuscript will not be referenced traditionally. Instead, I refer to the expatriates quoted in this paper (who are part of these communities on Facebook) as "expatriate[s]" or "member[s]" without a referenced entry to protect their privacy. The timeframe for the analyzed posts is between January 2016 and December $2019 .^{3}$

\section{Research Design}

This research consists of the discourse analysis of naturally occurring conversations in four major Facebook groups for expatriates in Mexico with observational notes supporting it. I used a discursive analysis methodology to uncover the dynamics between social context, language, and action in virtual communities. To understand why expatriates in Mexico need to resort to Facebook groups, I draw inspiration from Foucault's findings in discourse analysis

\footnotetext{
${ }^{3}$ I selected this date rage to avoid posts related to the Covid-19 pandemic in 2020.
} 
methods that reveal how the formation of social context is influenced by language and from the assessment that the discourse generated within a social context is embedded with frameworks that bring power structures to the surface (Miles, 2012).

Since access to information, people that influence, and experience are social capital resources fundamentally embedded in social networks (Lin, 1999), the direct access to experienced expatriates is a social capital resource embedded in Facebook groups. The purpose of analyzing the texts from expatriates on Facebook groups is to show how the discursive practices that construct bodies of knowledge in these groups translate into social capital. In order to demonstrate how discursive practices in Facebook groups for expatriates in Mexico translate into social capital, I designed a composite picture to represent the data gathered from these Facebook groups. The design of this composite picture consists in the adaptation of the proposed framework on Lin's (2008) network theory of social capital to assess the capacity and usage of social networks among groups to achieve particular (or personal) goals. In this composite picture I explore two questions as a framework for the analysis, what is the capacity of Facebook to generate social capital returns? And how does the usage of Facebook groups influence onlineoffline social capital?

\section{History of the North American Community in Mexico}

The number of North Americans who lived as expatriates in Mexico was relatively small until the 1980s. In the earlier era, this small group of expatriates was mainly composed of professionals (Rodríguez \& Cobo, 2012b), veterans (Kandell, 2010), writers (Cave, 2013), artist (Gessell, 2015), religious minorities (Rodríguez \& Cobo, 2017), exiles (Zolov, 2003), and intellectuals (Burke, 2017). In 1926 the Mexican census counted their foreign population for the first time. There were 15,219 Americans and 6,447 Canadians residing in Mexico (Rodríguez \& 
Cobo, 2017). The small North American population changed in the 1980s as the number of Americans living in Mexico increased rapidly, probably due to the reduced social safety net beginning with the Reagan administration in the 1980s. ${ }^{4}$ Mindes (2019) cites World Bank figures estimating that in 1980, 160,890 Americans were living in Mexico. In the following decade (1990), that number rose to 200,000 (Mindes, 2019) and continued to rise through the 1990s.

The low yet guaranteed economic security that veteran benefits and social security (for retirees) provide for many Americans indirectly facilitated and influenced their decision to migrate to Mexico. The main reason why economic security through governmental policies facilitates and influences the decision to migrate is that social security payments are often not enough for Americans to maintain their previous standard of living, let alone an improved one. Places like Mexico attract some American middle-class retirees because a) dollars offer more buying power over the local currency (Hayes, 2015; Lizárraga Morales, 2008) b) social security payments are enough to cover migration income requirements ${ }^{5}$ c) proximity: veterans and

${ }^{4}$ During the administration of President Franklin D. Roosevelt, the United States' focus on domestic affairs resulted in policies centered on economic security to lift people out of poverty. The primary focus of these policies was the welfare of veterans, elders, and children. Social Security Amendments of 1983 reduced social security payments to the extent that they do not reflect the current cost of living in the US. Also, health services were significantly reduced over time. See Social Security History. (n.d.). Retrieved March 25, 2021, from https://www.ssa.gov/history/briefhistory 3.html and Text S.1 - 98th Congress (1983-1984): Social Security Amendments of 1983. (1983, April 6). https://www.congress.gov/bill/98th-congress/senate-bill/1/text.

${ }^{5}$ The Mexican government offers temporary residence to foreigners who intend to be in Mexico for more than 180 days and less than 4 years if they can prove economic solvency. In order to prove economic solvency, most Americans use their social security income. Proving economic solvency consist of 12 consecutive months of 5,000 days of minimum wage ( $\$ 35,660$ USD) and monthly income of 300 days of minimum wage ( $\$ 2,114$ USD in the interior of Mexico and $\sim \$ 3,222$ USD in the free trade zone along the US-Mexico border, effective in 2021). See Residente temporal y trabajo. (2020). Secretaria de Relaciones Exteriores. https://embamex.sre.gob.mx/chile/index.php/servicios-consulares/visas/vtemporal 
retirees receive some medical insurance as part of their social safety programs valid only in the United States. $^{6}$

\section{North Americans in Mexico: Locations and Numbers}

While it is true that the magnitude of immigration to Mexico is reasonably small compared to the magnitude of the immigration to the United States or Canada (Rodríguez \& Cobo, 2012a). ${ }^{7}$ Americans represent the largest percentage of immigrants in Mexico. ${ }^{8}$ The Mexican census count of Americans living in Mexico has climbed sharply since $2000 .{ }^{9}$ In that year, the census counted 342,591 Americans. By 2010 there were, 738,103 Americans and it is estimated there were 797,266 in 2020 (Población Total Nacida En Otro País Residente En México Por Entidad Federativa Según Sexo y Países Seleccionados, 2000, 2010 y 2020, 2020).

${ }^{6}$ Social Security (established in 1935) is a government-run income benefit for retirees (65 and over) who have worked (and paid Social Security taxes) for at least ten years. Medicare (established in 1965 ) is also a government-run program for older Americans. It provides health insurance to anyone 65 or older who has worked (and paid Medicare taxes) for at least ten years. While these programs are not the same, both are run by the Social Security Administration. See Social Security History. (n.d.).

${ }^{7}$ The United States had 45 million foreign-born residents in 2019. From that number, approximately 10.9 million (24\%) were Mexican nationals. For more information about recent Mexican immigration to the United States, see Batalova, J., \& Israel, E. (2020). Mexican Immigrants in the United States. Migrationpolicy.Org. https://www.migrationpolicy.org/article/mexican-immigrants-united-states$\underline{2019}$

${ }^{8}$ Some of the Americans registered in the census as foreign-born have Mexican ancestry. These are children of Mexican immigrants (to the United States) who still have family in Mexico. Many of these American children end up in Mexico intending to reunite with their parent[s] who were deported due to their legal status. For more information about this growing phenomenon see Cave, D. (2012, June 19). American Children, Now Struggling to Adjust to Life in Mexico. The New York Times. https://www.nytimes.com/2012/06/19/world/americas/american-born-children-struggle-to-adjust-inmexico.html

${ }^{9}$ While there is no correlation between the usage of Facebook groups and an increase in the American expatriate population in Mexico. The premise is simple, expatriates found ways to use Facebook groups to meet their needs when they were launched. 
Americans made up 70 percent of all foreign-born people living in Mexico in the 2000 census (see Figure 2). In 2010 this percentage increased to 77 percent (see Figure 3), and in 2020, the percentage decreased to 66 percent (see Figure 4). ${ }^{10}$ The states of Baja California Norte, Chihuahua, and Jalisco have the most American expatriates (Población Total Nacida En Otro País Residente En México Por Entidad Federativa Según Sexo y Países Seleccionados, 2000, 2010 y 2020, 2020)

\section{Figure 2}

Foreign-born population residing in Mexico in 2000.

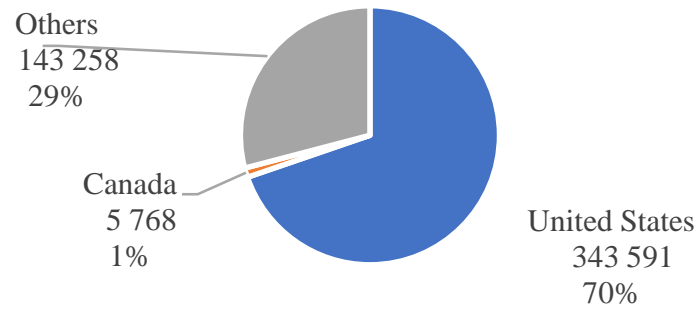

Note. The pie chart represents the number and percentage of Americans and Canadians residing in Mexico in the 2000 census. From INEGI. XII Censo General de Población y Vivienda 2000.

\section{Figure 3}

Foreign-born population residing in Mexico in 2010.

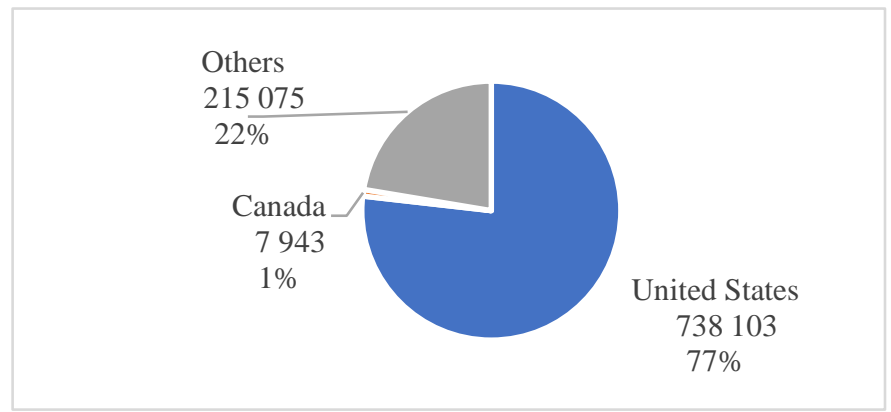

Note. The pie chart represents the number and percentage of Americans and Canadians residing in Mexico in the 2010 census. From INEGI. Censo de Población y Vivienda 2010.

${ }^{10}$ The decrease in the number of Americans in the 2020 census probably was affected by travel restrictions during the Covid-19 pandemic. 


\section{Figure 4}

Foreign-born population residing in Mexico in 2020.

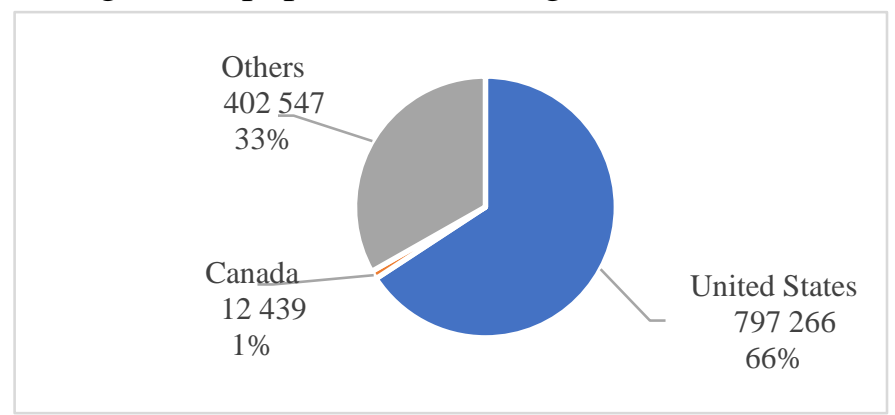

Note. The pie chart represents the number and percentage of Americans and Canadians residing in Mexico in the 2020 census. From INEGI. Censo de Población y Vivienda 2020.

Compared to Americans, the number of Canadians living in Mexico is small, but increasing. This trend becomes clear in 2000; the census of that year showed that the number of Canadians residing in Mexico reached 5,768 (see Figure 2). The 2010 and 2020 Mexican censuses reported a continuation of the same increasing trend. According to the Mexican census, in 2010, there were 7,943 Canadians, and in 2020, the number increased to 12,439 (see Figures 3 and 4). The Mexican census shows that Canadians are mainly concentrated in eight states. Five of these states have a coastline in the Pacific and Caribbean (see Figure 5).

The most significant concentration is in the state of Jalisco, with 20 percent of Canadian residents. The Federal District (D.F.) and Chihuahua are home for 12 percent, and Quintana Roo has 6 percent. Mexico state and Baja California Sur hosts 4 percent, Nayarit 3 percent, and Sinaloa 2 percent. The reminder 37 percent of all Canadian residents live across Mexico in smaller communities, which the census does not break down. ${ }^{11}$

${ }^{11}$ The Censo de Población y Vivienda 2020 (Mexican census) data set does not break down the geographical information below 2 percent. It is reasonable considering the state of Sinaloa had 115 people 


\section{Figure 5}

Canadians by geographical concentration

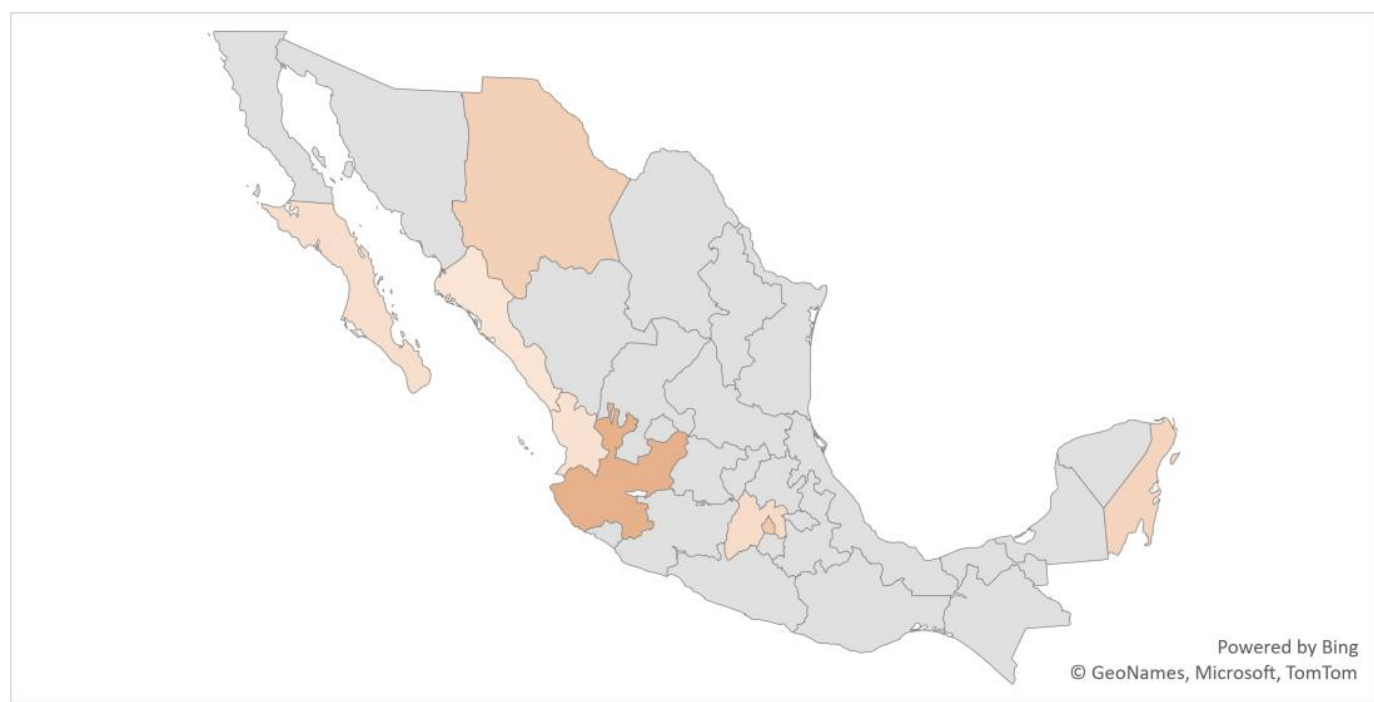

Note. Canadian population residing in Mexico in 2020 by concentration. From INEGI. Censo de Población y Vivienda 2020.

\section{North American Migration Process and Social Media}

The rapid growth of the North American expatriate community in the last 30 years intersects with the increase of internet penetration in Mexico. ${ }^{12}$ As an indirect result of the increasing internet penetration, it became easier for expatriates to create virtual communities on Facebook that are useful in helping each other navigate life and establish new networks in Mexico (see Footnote 1).

who represent 2 percent of the Canadian population in Mexico. See Instituto Nacional de Estadística y Geografía (2020).

${ }^{12}$ The internet penetration in Mexico was a little over 5 percent in 2000, and by 2020 it increased to 66 percent. See Mexico Internet Users. (n.d.). Retrieved May 2, 2021, from https://www.internetlivestats.com/internet-users/mexico/ and Newman, N., Fletcher, R., Schulz, A., Andi, S., \& Kleis Nielsen, R. (2020). Reuters Institute Digital News Report 2020. 112. 
North Americans' increasing presence in Mexico fits the characteristics of chain migration, and their usage of Facebook groups indicates that this is a burgeoning community. According to Kuhn (2015), typically, we can observe chain migration when there is high migration from one place followed by even higher migration at different societal levels (household, community, regional, and national). Unlike migration from the Global South to the Global North, North Americans who migrate to the Global South have a unique position. Expatriates who move to Mexico are not moving only for economic reasons. Hayes (2014) observes that North Americans are moving to South America seeking wellbeing and cultural authenticity in warm climates while simultaneously negotiating their changing economic circumstances as inequality grows in the Global North.

Migration studies offer the best theoretical framework to explain how North Americans end up in Mexico through chain migration. In the Turbulence of migration, Papastergiadis (2000) claims that people have been encouraged to migrate mainly by their own people since the late nineteenth and early twentieth century. North Americans display the same characteristic of being encouraged to move to Mexico through word of mouth by other North Americans. This encouragement was generally done through lifestyle, travel, and international living publications. ${ }^{13}$ More recently, Facebook groups provide a virtual space for North Americans who are planning on relocating to Mexico to explore different lifestyle options. For example, one expatriate wrote, "I'm thankful for this group. As I am all for sharing the love and concern for

${ }^{13}$ This paper assumes lifestyle publications in English are mean to be for Canadian and American audiences since their countries are the only ones in North America that are English-speaking. 
strangers!" This reciprocity is particularly beneficial to prospective expatriates as experienced expatriates are open to sharing their experiences in these groups and helping each other.

Facebook innovations in digital technology and communications extended expatriates' ability to link published content like books, websites, and YouTube ${ }^{14}$ videos promoting Mexico. Whether the content is digital or in print, the claims of a low cost of living and higher quality of life are mainly supported by the exchange rate from US dollars to Mexican pesos that benefit North Americans in Mexico who have dollars. ${ }^{15}$ These publications promote Mexico as a place that offers a low cost of living while gaining a better quality of life than in North America. The phenomenon of migration from the Global North to South is not new, but it has increased rapidly in the last three decades (Gosnell \& Abrams, 2011; Hayes, 2014; Torkington, 2012).

\section{Discourse Analysis}

\section{What is the Capacity of Facebook to Generate Social Capital Returns?}

If one considers that social capital is a driver for migration, and migration is driven by a "desire to leverage existing capital to either enhance or protect future livelihood opportunities" (Kuhn, 2015 p. 437) it becomes easy to see that migrants' (in this case, expatriates) successful

\footnotetext{
${ }^{14}$ YouTube has a wealth of videos from expatriates video-documenting their experiences living in Mexico, regularly linked to Facebook posts.

${ }^{15}$ In 1995 the average exchange rate was 6.42 MXN per every 1 USD. In 2000 the average exchange was 9.46 MXN per every 1 USD. In 2010 it was $12.62 \mathrm{MXN}$ per $1 \mathrm{USD}$, and in 2020 was 21.48 MXN per 11 USD. US Dollar Peso Exchange Rate (USD MXN)-Historical Chart. (n.d.). Retrieved April 9, 2021, from https://www.macrotrends.net/2559/us-dollar-mexican-peso-exchange-rate-historicalchart. In 1995, the average exchange rate from Canadian dollars to Mexican pesos was MXN 4.70 per 1 CAD. In 2000 the average rate was 6.36 MXN per 1 CAD. In 2010, 12.26 MXN per 1 CAD, and in 2020 was 15.99 MXN per 1 CAD. See Historical Exchange Rates Tool \& Forex History Data. (n.d.). OFX. Retrieved April 9, 2021, from https://www.ofx.com/en-us/forex-news/historical-exchange-rates/
} 
outcome in navigating the nuances of a foreign country is what makes chain migration possible (Papastergiadis, 2000). Perhaps, this is the simple explanation of why several North Americans are resourcing to Facebook groups before migrating. They are using it to gauge the extent to which they can leverage their existing capital in Mexico and begin to develop support networks if they decide to move. Facebook groups are the logical continuation in the series of digital social networks North Americans use to make their plans when considering retirement outside the United States (see Footnote 1).

\section{The Role of Facebook in Expatriates' Decision Making}

Facebook groups have the potential to have an important role in expatriates' decisionmaking. The fact that to join these communities, people do not have to be physically present in Mexico means expatriates could choose where to go based on information found in these groups, essentially online shopping for where to retire. One group, for example, in their "about" section, describes itself as a place where "ex-pats, wannabe ex-pats, and former ex-pats can share stories, ask for and give advice, and support one another." Another large group describes itself as a "support group where expatriates can share common interests, experiences, and learnings and enjoy networking opportunities." Similarly, another group claims to be a "forum for people planning or thinking about moving to Mexico. It [the group] is intended to be a place where people can ask questions to other people who have made the move." Yet, another group states that it is for "expatriates interested in visiting and/or living in Mexico." Thus, the usage of Facebook groups has the potential to be a significant role-player in their decision-making, especially when the "about" section of these communities has narratives that explicitly say this.

The fast-paced advancement of digital technology provides new ways for North American expatriates to gain and maintain their social capital in a new country. Digital 
technology is a tool for survival (Vallee, 1982) into a new phase in social relations (Hancock, 2009; Thurlow, 2018). In virtual expatriate communities, this new phase manifests in how expatriates use Facebook groups to gain cultural knowledge and social networks that increase social capital. Rheingold (2000) claims that using computer-mediated communications (CMC) is like a groupmind of sorts where "the experience has to do with the way groups of people are using CMC to rediscover the power of cooperation, turning cooperation into a game, a way of life--a merger of knowledge capital, social capital, and communion" (p. 96). If one considers that the outcomes from using social media depend on the way people use it, it is not surprising that when Facebook launched Facebook groups, expatriates would use them to congregate and develop social networks that adhere to the same principles of structure and action present in social capital theory. ${ }^{16}$

When people have transnational lives, their social networks change over time, affecting people's social capital (Casado-Díaz et al., 2014). So, when people change geographic locations, it often means a loss in social networks and the social capital these networks represent (Ellison et al., 2007). Expatriates use Facebook groups to counter their social networks' loss and to gain and maintain their social capital in a new location. Facebook groups for expatriates are beneficial to maintain and accumulate social capital during the transition from one offline community to another (Ellison et al., 2007) because online communities are borderless (McDonnell, 2009). As one expatriate put it, the support from other expatriates in Facebook groups can make the

${ }^{16}$ Lin (1999) suggests an interactive approach to analyzing social capital theory by focusing on the structure and action in micro and macro social processes that follow a premise of "investment in social relations with expected returns" (p. 30). 
transition "less daunting." In addition, Facebook groups provide North American expatriates with space to create a community and find support.

\section{The Dynamics of Discussions}

Experienced expatriates who partake in these groups have a wealth of information about living in Mexico that influences and possibly enhances the outcomes of other expatriates who belong to these groups. Generally, expatriates in these Facebook groups can be separated into two, experienced expatriates who have a wealth of information about living in Mexico and less experienced expatriates seeking information from seasoned expatriates. Less experienced expatriates display a willingness to ask for the advice of those who have more experience, and experienced expatriates are willing to provide this advice. ${ }^{17}$

Typically, the discussion starts with a less experienced expatriate asking for help with something unfamiliar. Then, people who know about the specific issue inquired about, comment on it. The best example of how many discussions between experienced and less experienced expatriates begin is the following post from a less experienced expatriate seeking advice in one of these large groups. The expatriate's post explained how, despite liking Mexican culture, his lack of knowledge about Mexico (as a political country) prevented him from initiating the move because he did not know where to start. He posted:

I have always liked Latin and Mexican Culture. I would love to move to Mexico [...]. I want to relocate, but I don't know where to start. What areas are expatriate-friendly? Are drug cartels an issue? What is the cost of living? Can I buy property there, or is it best to

${ }^{17}$ On rare occasions, outliers advise not to move to Mexico and further share why they decided not to move to Mexico or leave Mexico. I explore the latter concept in another section of this paper. 
rent? What is health care like in Mexico? Is it wise to take a vehicle or buy one there? I have too many questions. (Expatriate in a Facebook group)

Posts like the one above tend to generate hundreds of comments from experienced expatriates giving tips, anecdotes, suggestions, and sometimes referring to different relocation services. A considerable portion of the comments generated from discussions initiated by prospective expatriates include links to books, YouTube channels, and other Facebook groups expatriates in Mexico claim they used to inform their decision to move (see Footnote 14).

Expatriates in Mexico turn to Facebook groups with questions about the culture or other myriad of things they encounter foreign to them. To get more accurate answers, expatriates attach pictures to their posts to illustrate their inquiries. It is prevalent to see pictures of insects, food, plants, utility bills, places, people, cars, pets, businesses, houses, shoes, appliances, electronics, furniture, and the list goes on. Expatriates use these groups because they do not know much about life in Mexico, but they want to learn. ${ }^{18}$ With similar interests in community building, experienced expatriates share their insights and experiences living in Mexico when people post questions in these Facebook groups.

The rationale for the interactions among expatriates (new and longtime expatriates) and between established and prospective expatriates is to avoid costly mistakes that for longtime expatriates are a lived experience. The added value of these groups is for potential expatriates who join as it offers them the opportunity to gain firsthand knowledge from current expatriates well before moving. So, when potential expatriates begin the move and encounter

${ }^{18}$ What is unclear is if the people who end up moving would stay. While there is no reliable data on how many expatriates repatriate. A study about retired expatriates in Lake Chapala indicates that many expatriates who returned did it to be close to their children, grandchildren, or both (Banks, 2009). 
situations they read on the discussions from these groups, it is not entirely new. In addition, it offers them a large and widely spread community they can tap as they need it. Established expatriates (new and longtime) and prospective expatriates essentially use Facebook groups' platforms to create bodies of knowledge.

\section{How does the Usage of Facebook Groups Influence Online-Offline Social Capital?}

The prevalence of social media among expatriates facilitates and accelerates how social capital is derived from social connections. According to Zúñiga et al. (2017), the connection between "offline social capital" and "social media social capital" is "symbiotic, yet asymmetrical" (p. 61). It is symbiotic because the offline social capital generated from social media social capital depends on how people connect the two, and it is asymmetrical because social media social capital influences peoples' behavior offline and online, more so than offline social capital (Zúñiga et al., 2017). Facebook groups for expatriates display the same symbiotic and asymmetrical connection. The social capital social media these groups provide translates into real capital when used to ask and advise to reduce the financial risks of establishing residency in a foreign country. In many ways, expatriates (potential and established) join these groups because expatriates benefit more from the advice of expatriates on Facebook who are strangers (but have experience) than from acquaintances or relatives who may have little to no knowledge about living in Mexico.

\section{Safety Concerns Bring Expatriates Together}

Although over a million expatriates go to Mexico every year, in recent years the country has developed a reputation for being unsafe. This reputation is reflected in the plenty of discussions created to inquire if Mexico is safe to visit or live. Expatriates ask questions like, "what places are safe?" what places should they "avoid?" and "how realistic are safety 
concerns?" For example, one expatriate posted a question asking if it is safe for a woman to drive alone to Mexico. She further explains her situation and says, "I'm considering retirement there [Mexico]. I'd like to drive there to get away and see what it's like." After receiving over 100 responses, the expatriate updated the discussion post expressing how thankful she was for the information and advice she received from members of the group.

Thank you to each one personally for being so positive and hopeful! Mexico is a paradise within driving distance, I've always believed, but whenever I say I want to go, I'm met with how dangerous it is, any more dangerous than anywhere else. It's paradise! (an expatriate in a Facebook group)

Many posts like the one above include statements indicating they are discouraged from moving to Mexico by non-expatriate relatives or friends. In addition to the concerns of relatives and friends, many expatriates credited their concerns to the continued travel advisories from the Department of Homeland Security ${ }^{19}$ and the media reports of drug-related violence in Mexico. From the perspective of long-time expatriates, Mexico's reputation for being unsafe, while a real issue, is largely overblown. For those who voice their opinion on the matter, safety has to do with the intentions and motivations of expatriates in moving to Mexico. "The perception of danger should be [...] of concern only if one is seeking to buy or sell drugs or other contraband," one expatriate stated, expressing his disagreement with the perception of Mexico as

19 To see the travel advisories to Mexico from the Department of Homeland Security. See Mexico Travel Advisory. (n.d.). Retrieved May 21, 2021, from https://travel.state.gov/content/travel/en/traveladvisories/traveladvisories/mexico-traveladvisory.html 
a dangerous place. ${ }^{20}$ The expatriate continued and said: "the broad media critical view on Mexico is, to put it mildly, wrong, and the significant numbers of Americans living there all or part of each year prove my point." Expatriates also recognize that there are occasions when they are the subject of petty crime. "As with the U.S., there are some unsafe areas, which can be learned and avoided," one expatriate said. Another expatriate commented, "Mexico can be a dangerous place," but if one successfully "sorts out the people who know from the people who don't [...] it's worth it," he added.

The quotes above show two aspects of expatriates as a group of people. 1) shows how long-time expatriates gained and maintained their social capital through cultural knowledge acquisition in order to have a social network in Mexico 2) shows how social capital is exhibited in social networks. It is undeniable that the number of North Americans living in Mexico has soared in the last 20 years. So, if their numbers increased it is because, for the most part, they are not the subject of violent crimes. Still, safety concerns are prominent in expatriate communities. Undoubtedly, Facebook groups foster a sense of community among those who already live there, and it engages those who have not. The latter is more apparent when realizing that prospective expatriates engage in conversation after thinking about these concerns. Then, they turn to these groups to reinforce their decision and assess under what circumstances they would do it.

${ }^{20}$ Around the time of this post, a family of American expatriates was killed. The news prompted rampant speculations in Facebook groups regarding the reasons for the murder of this family. See Allyn, B. (2019). FBI Joins Investigation into Killing Of 9 Members Of Mormon Family In Mexico. NPR. https://www.npr.org/2019/11/11/778318135/fbi-joins-investigation-into-killing-of-9-members-ofmormon-family-in-mexico 


\section{Social Capital Reinforcements}

Social capital reinforcements reinforce the values, beliefs, and worth of those who belong to a group (Lin, 1999). The purpose of having these reinforcements is to ensure a continuation of the social capital that the group generates. One expatriate pointed out how this reinforcement occurs in Facebook groups for expatriates, although he misunderstood its significance. He said, "asking in an expatriate group if Mexico is safe is like asking in a pizza lovers' group if pizza is healthy," referring to expatriates who pose their safety concerns. Some readers may miss the point like the expatriate and question whether partaking and getting information from these selffeeding groups contributes to the expatriate's social capital. Lin (1999) explains that these reinforcements are part of the process of accessing and mobilizing others with similar interests to reinforce their overall social capital.

Besides discussing where to live that is safe, expatriates constantly have migration questions. $^{21}$ "Should I go on a tourist visa?" "My visa expired. Now what I do?" "should I get a residency?" "What type of residency is better, temporary or permanent?" All these questions are widespread in these groups while addressing migration inquiries. More experienced expatriates tend to provide information that helps less experienced expatriates solve their problems while figuring out the Mexican migration system. Expatriates, for example, will provide information about books, relocation services, and attorneys they have used to get care of their legal matters.

${ }^{21}$ It is remarkable how open they are talking about living in Mexico without the proper documentation. That said, what entitles being legal or illegal for a North American expatriate in Mexico is blurry as per the law; tourists can rent and purchase property in Mexico. So, technically if expatriates maintain a non-expired tourist visa, they are legally in the country. See Acquisition of properties in Mexico. (n.d.). Secretaria de Relaciones Exteriores. Retrieved May 21, 2021, from https://consulmex.sre.gob.mx/reinounido/index.php/en/servicios/218-acquisition-of-properties-in$\underline{\text { mexico. }}$ 
The reciprocity creates a cycle that reinforces expatriates' desires to migrate while they are having difficulties migrating. It also reinforces the success of long-time expatriates when they share this information.

If one considers these reinforcements as a fundamental part of the process of gaining and maintaining social capital, it makes sense that there is a general tendency to encourage potential expatriates to move to Mexico as this increases their pool of resources. This helps explain why (as a group of people) expatriates live in enclave communities. Further, their economic standing coming from a wealthier country makes their buying power (and presence) more significant than their sheer numbers (see the section in the historicization of the North American community in Mexico). In other words, this reinforcement is not only psychological. It is material too. Enclave communities for expatriates are the primary example of how these reinforcements link social networks and media networks, a linkage that social media enhances.

\section{Conclusions}

North American expatriates are migrating to Mexico in order to increase the buying power of their dollars. The widening wealth gap between the rich and the poor is why some middle-class-income North Americans are choosing to move to Mexico. They see Mexico's low cost of living as an opportunity to continue a middle-class lifestyle at a fraction of what it would cost in the United States or Canada. Unfortunately, many of the expatriates who plan to move to Mexico do not speak Spanish or have cultural knowledge of how life is like in Mexico and live in expatriate communities.

Traditionally, if people wanted to know about Mexico before moving, they had to read a combination of travel and lifestyle magazines or other travel guides. With the advance of digital technology, expatriates have been able to communicate at a faster pace using list servers, blogs, 
and social media. The borderless capabilities of social media platforms like Facebook provide a virtual space for expatriates to create bodies of knowledge that translate into social capital. Facebook groups capture the processes and cycles that make social capital work by the mere fact that it allows people to congregate and interact in these groups.

The paper's analysis shows that Facebook groups for expatriates can generate social capital returns as most of the information solicited in these groups helps prevent situations that compromise their financial well-being. Of course, this motivation to avoid losing money aligns with their initial motives to move to Mexico in the first place. The ability of new expatriates to use Facebook groups to solicit information from experienced expatriates reinforces the social capital of both. It is a reinforcement for new expatriates because there are financial and networking gains from partaking in them. For experienced expatriates, it reinforces the value of their experience in the community. In short, Facebook groups for expatriates, to a certain extent, help North American expatriates navigate their lives in Mexico by providing a widespread community that transcends borders. 


\section{References}

Alcocer-Berriozabal, M. (2000). The structure and development of the American expatriate community in Mexico City since World War II [Doctoral dissertation, University of Kansas]. https://search.proquest.com/docview/304603175/abstract/385CCE6B7DA467BPQ/1

Banks, S. P. (2004). Identity narratives by American and Canadian retirees in Mexico. Journal of Cross-Cultural Gerontology, 19(4), 361-381. https://doi.org/10.1023/B:JCCG.0000044689.63820.5c

Banks, S. P. (2009). Intergenerational ties across borders: Grandparenting narratives by expatriate retirees in Mexico. Journal of Aging Studies, 23(3), 178-187. https://doi.org/10.1016/j.jaging.2007.11.004

Burke, P. (2017). Exiles and expatriates in the history of knowledge, 1500-2000. Brandeis University Press. https://muse.jhu.edu/book/49570

Casado-Díaz, M. A., Casado-Díaz, A. B., \& Casado-Díaz, J. M. (2014). Linking tourism, retirement migration and social capital. Tourism Geographies, 16(1), 124-140. https://doi.org/10.1080/14616688.2013.851266

Cave, D. (2013, October 11). Kerouac's Mexico. The New York Times. https://www.nytimes.com/2013/10/13/travel/kerouacs-mexico.html

Croucher, S. (2009). Migrants of privilege: The political transnationalism of Americans in Mexico. Identities, 16(4), 463-491. https://doi.org/10.1080/10702890903020984

Ellison, N. B., Steinfield, C., \& Lampe, C. (2007). The benefits of Facebook “friends:" Social Capital and college students' use of online social network sites. Journal of Computer- 
Mediated Communication, 12(4), 1143-1168. https://doi.org/10.1111/j.1083-

6101.2007.00367.x

Gessell, P. (2015, February 19). San Miguel: Western Canada's connection to Mexico. Galleries West. https://www.gallerieswest.ca/api/content/18a0fd02-982d-11e4-91a7-22000a4f82a6/

Gosnell, H., \& Abrams, J. (2011). Amenity migration: Diverse conceptualizations of drivers, socioeconomic dimensions, and emerging challenges. GeoJournal, 76(4), 303-322. https://doi.org/10.1007/s10708-009-9295-4

Goss, D. R. (2019). "It's like going back in time": How white retirees use expatriation to reclaim white dominance. Sociological Perspectives, 62(4), 538-553. https://doi.org/10.1177/0731121418817250

Hancock, P. A. (2009). Mind, machine and morality: Toward a philosophy of human-technology symbiosis. Ashgate Publishing, Ltd.

Hayes, M. (2014). 'We gained a lot over what we would have had': The geographic arbitrage of North American lifestyle migrants to Cuenca, Ecuador. Journal of Ethnic and Migration Studies, 40(12), 1953-1971. https://doi.org/10.1080/1369183X.2014.880335

Hayes, M. (2015). Moving South: The economic motives and structural context of North America’s emigrants in Cuenca, Ecuador. Mobilities, 10(2), 267-284. https://doi.org/10.1080/17450101.2013.858940

Kandell, J. (2010, December). Under the spell of San Miguel de Allende. Smithsonian Magazine. https:/www.smithsonianmag.com/travel/under-the-spell-of-san-miguel-de-allende$71084706 /$ 
Kuhn, R. (2015). Internal migration: Developing countries. In International Encyclopedia of the Social \& Behavioral Sciences (pp. 433-442). Elsevier. https://doi.org/10.1016/B978-008-097086-8.31120-5

Kunz, S. (2020). Expatriate, migrant? The social life of migration categories and the polyvalent mobility of race. Journal of Ethnic and Migration Studies, 46(11), 2145-2162. https://doi.org/10.1080/1369183X.2019.1584525

Lin, N. (1999). Building a Network Theory of Social Capital': Vol. 22(1). Connections. https://citeseerx.ist.psu.edu/viewdoc/download?doi=10.1.1.96.3792\&rep=rep1\&type=pdf Lin, N. (2008). A network theory of social capital. In D. Castiglione, J. W. van Deth, \& G. Wolleb, The handbook of Social Capital (pp. 50-69). Oxford University Press.

Lizárraga Morales, O. (2008). La inmigración de jubilados estadounidenses en México y sus prácticas transnacionales: Estudio de caso en Mazatlán, Sinaloa y Cabo San Lucas, Baja California Sur. Red Internacional de Migración y Desarrollo, 11, 97-117.

Markham, A. (2012). Fabrication as ethical practice: Qualitative inquiry in ambiguous internet contexts. Information, Communication \& Society, 15(3), 334-353. https://doi.org/10.1080/1369118X.2011.641993

McDonnell, J. (2009). Crossing borders in virtual space. Media Development, 56(4), 3-7.

Mexico Internet Users. (n.d.). Retrieved May 2, 2021, from https://www.internetlivestats.com/internet-users/mexico/

Miles, B. (2012). Discourse analysis. In N. Salkind (Ed.), Encyclopedia of Research Design (pp. 368-370). SAGE Publications, Inc. https://doi.org/10.4135/9781412961288 
Mindes, S. C. H. (2019). Emigrant America: Estimating and envisaging expatriation to Canada and Mexico [Doctoral dissertation, Michigan State University]. https://search.proquest.com/docview/2211063504/abstract/D5065656CCCC4D6DPQ/1

Papastergiadis, N. (2000). The turbulence of migration: Globalization, deterritorialization and hybridity. Wiley.

Población total nacida en otro país residente en México por entidad federativa según sexo y países seleccionados, 2000, 2010 y 2020. (2020). [Census]. Instituto Nacional de Estadística y Geografía. https://www.inegi.org.mx/app/tabulados/interactivos/?pxq=Migracion_Migracion_03_79 3b2477-4037-43d4-9a60-90fb2592cdbc

Rheingold, H. (2000). The virtual community: Homesteading on the electronic frontier (Rev. ed.). MIT Press.

Rodríguez, E., \& Cobo, S. (2012a). Extranjeros residentes en México: Una aproximación cuantitativa con base en los registros administrativos del INM (Primera edicion). Centro de Estudios Migratorios, Instituto Nacional de Migracion, Secretaría de Gobernación.

Rodríguez, E., \& Cobo, S. (2012b). Los canadienses en México: Una aproximación histórica y sociodemográfica a sus procesos de inmigración y de movilidad internacional reciente. Migration Policy Institute, 34.

Rodríguez, E., \& Cobo, S. (2017). Los canadienses en México. Inmigración y movilidad internacional. Migraciones internacionales, 9(1), 9-42.

Thurlow, A. (2018). Social media, organizational identity and public relations: The challenge of authenticity. Routledge. 
Torkington, K. (2012). Place and lifestyle migration: The discursive construction of 'glocal' place-identity. Mobilities, 7(1), 71-92. https://doi.org/10.1080/17450101.2012.631812

Truly, D. (2002). International retirement migration and tourism along the Lake Chapala Riviera: Developing a matrix of retirement migration behaviour. Tourism Geographies, 4(3), 261281. https://doi.org/10.1080/14616680210147427

Vallee, J. (1982). The network revolution: Confessions of a computer scientist. Jacques Vallee.

Willis, R. (2018). The use of composite narratives to present interview findings: Qualitative Research. https://doi.org/10.1177/1468794118787711

Zolov, E. (2003). A gathering of fugitives: American political expatriates in Mexico, 1948-1965 (review). The Americas, 60(2), 280-281. https://doi.org/10.1353/tam.2003.0121

Zúñiga, H. G. de, Barnidge, M., \& Scherman, A. (2017). Social media Social Capital, offline Social Capital, and citizenship: Exploring asymmetrical Social Capital effects. Political Communication, 34(1), 44-68. https://doi.org/10.1080/10584609.2016.1227000 